\title{
Eksistensi Hak Budget DPR Dalam Sistem Ketatanegaraan Indonesia
}

\author{
Mei Susanto*
}

\begin{abstract}
Abstrak
Eksistensi hak budget Dewan Perwakilan Rakyat (DPR) dalam sistem ketatanegaran Indonesia pada saat ini setidaknya menimbulkan dua persoalan. Pertama, mengenai keberadaan hak budget DPR, khususnya setelah dihapuskannya Penjelasan UUD Tahun 1945. Kedua, persoalan mengenai urgensi keterlibatan DPR dalam pembahasan Rancangan Anggaran Pendapatan dan Belanja Negara (RAPBN) yang didalamnya muncul perdebatan mengenai sejauh mana keterlibatan DPR dalam pembahasan RAPBN tersebut. Pada praktiknya pun terjadi penyalahgunaan hak budget oleh oknum anggota DPR. Akibatnya muncul keinginan mengevaluasi hak budget DPR tersebut. Melalui Putusan No. 35/PUU$\mathrm{XI} / 2013$, Mahkamah Konstitusi telah memangkas keterlibatan DPR dalam pembahasan RAPBN yang mendetil dari satuan unit organisasi, fungsi, program, kegiatan, dan jenis belanja menjadi hanya sampai unit organisasi, fungsi, dan program saja. Putusan Mahkamah Konstitusi tersebut dianggap telah mereposisi hak budget DPR. Namun, dalam praktiknya masih terjadi korupsi anggaran yang dilakukan oknum anggota DPR.
\end{abstract}

Kata Kunci: APBN, DPR, fungsi anggaran, hak budget, RAPBN.

\section{The Existence of the Right of Budget of the House of Representatives in the Constitutional System in Indonesia}

\begin{abstract}
The existence of the right budget of the House of Representatives (DPR) in the constitutional system in Indonesia at this moment at least raises two issues. First, regarding the existence of the right budget of the House of Representatives in particular after the removal of Explanation of the Constitution of 1945. Second, the question of the urgency of the House of Representatives involvement in the discussion of the Draft State Budget (draft budget) in which there is a debate about the extent of the involvement of House of Representatives in the discussion of the draft budget. In practice, there is misuse of rights budget by unscrupulous members of the House of Representatives which arises the desire to evaluate the rights budget of the House of Represntatives. Through Decision No. 35/PUU-XI/2013, the Constitutional Court has slashed the involvement of Parliament in the discussion of the detailed draft budget of the unit of the organization, functions, programs, activities and types of expenditure being only to organizational units, functions, and programs only. The Constitutional Court's decision is deemed to have rights to reposition the House budget. However, in practice budget corruption committed by individual members of Parliament still occurs.
\end{abstract}

Keywords: the state budget, House of Representatives, the budget function, right of budget, draft budget.

PADJADJARAN Jurnal IImu Hukum Volume 3 Nomor 1 Tahun 2016 [ISSN 2460-1543] [e-ISSN 2442-9325]

* Dosen Hukum Tata Negara Fakultas Hukum Universitas Padjadjaran, Jl. Dipati Ukur No. 35, Bandung, Pengurus Asosiasi Sarjana Hukum Tata Negara (ASHTN) Indonesia, m.susanto@unpad.ac.id, S.H. (Universitas Padjadjaran), M.H. (Universitas Indonesia). 


\section{A. Pendahuluan}

Eksistensi hak budget Dewan Perwakilan Rakyat (DPR) dalam sistem ketatanegaran Indonesia pada saat ini setidaknya menimbulkan dua persoalan. Pertama, mengenai keberadaan hak budget DPR khususnya setelah dihapuskannya Penjelasan Undang-Undang Dasar 1945 (UUD 1945). Kedua, persoalan mengenai urgensi keterlibatan DPR dalam pembahasan Rancangan Anggaran Pendapatan dan Belanja Negara (RAPBN) yang didalamnya muncul perdebatan mengenai sejauh mana keterlibatan DPR tersebut.

Jika Sebelum Perubahan UUD Tahun 1945, ketentuan hak budget muncul dari ketentuan yang mengatur proses pembahasan Anggaran Pendapatan dan Belanja Negara (APBN) yang diajukan pemerintah ke DPR dalam Pasal 23 Ayat (1):

Anggaran pendapatan dan belanja ditetapkan tiap-tiap tahun dengan undang-undang. Apabila Dewan Perwakilan Rakyat tidak menyetujui anggaran yang diusulkan pemerintah, maka pemerintah menjalankan anggaran tahun yang lalu.

Dalam penjelasan pasal tersebut disebutkan, "Ayat 1 memuat hak begrooting Dewan Perwakilan Rakyat. Hak begrooting atau hak budget ini menempatkan Dewan Perwakilan Rakyat pada posisi yang kuat ...". Dengan melihat Penjelasan Pasal 23 Ayat (1) tersebut, maka secara tegas expressis verbis eksistensi hak budget DPR diakui, mengingat sebelum perubahan, UUD Tahun 1945 terdiri dari Pembukaan, Batang Tubuh, dan Penjelasan. Maka dari itu tidak ada yang mempertanyakan hak budget DPR dalam ketatanegaraan Indonesia, karena tegas diakui dan disebutkan.

Hal berbeda terjadi setelah Perubahan UUD 1945, yang menghapuskan Penjelasan. ${ }^{1}$ Sebagai akibatnya, istilah hak budget pun tidak muncul sama sekali sehingga pengaturan mengenai mekanisme pembahasan APBN hanya ada dalam Pasal 23 yang disebutkan:

Ayat (2) "Rancangan undang-undang anggaran pendapatan dan belanja negara diajukan oleh Presiden untuk dibahas bersama Dewan Perwakilan Rakyat dengan memperhatikan pertimbangan Dewan Perwakilan Daerah."

Ayat (3) "Apabila Dewan Perwakilan Rakyat tidak menyetujui rancangan anggaran pendapatan dan belanja negara yang diusulkan oleh Presiden, Pemerintah menjalankan Anggaran Pendapatan dan Belanja Negara tahun yang lalu".

Akibat dihilangkannya Penjelasan UUD Tahun 1945, terdapat ahli yang berpendapat bahwa DPR tidak lagi memiliki hak tersebut. Sebagai contoh, Ronny

\footnotetext{
Aturan Tambahan Undang-Undang Dasar 1945 (UUD 1945) Setelah Perubahan Pasal II: “Dengan ditetapkannya perubahan Undang-Undang Dasar ini, Undang-Undang Dasar Negara Republik Indonesia Tahun 1946 terdiri atas Pembukaan dan pasal-pasal."
} 
Sautma Hotma Bako menyatakan bahwa akibat dari dihilangkannya Penjelasan UUD 1945 setelah Perubahan UUD 1945, maka fungsi anggaran tidak diikuti lagi dengan adanya hak budget dalam menentukan anggaran negara. ${ }^{2}$ Itu artinya Perubahan UUD 1945 telah menghapuskan eksistensi hak budget DPR tersebut. Beranjak dari situ, tulisan ini hendak membedah ketepatan dari pernyataan tersebut.

Selain itu, hal yang lebih mendasar berkaitan dengan eksistensi hak budget DPR adalah mengenai keterlibatan DPR dalam pembahasan RAPBN. Apabila mengunakan pendapat Montesquieu yang memisahkan kekuasaan dalam tiga bentuk, yakni eksekutif, legislatif, dan yudikatif, maka DPR sebagai lembaga legislatif semestinya fokus kepada pembuatan undang-undang yang isinya mengatur kehidupan berbangsa dan bernegara, bukan malah turut campur dalam urusan anggaran yang biasanya merupakan domain eksekutif. Berdasaran hal tersebut kemudian timbul pertanyaan mengenai makna dari pengajuan setiap APBN oleh pemerintah dan disetujui DPR yang bentuk hukumnya harus undang-undang.

Persoalan hak budget DPR tersebut semakin pelik jika melihat praktik penyelenggaraan negara Indonesia saat ini adalah terbongkarnya korupsi anggaran oleh Anggota DPR yang berkaitan erat dengan pembahasan RAPBN. ${ }^{3}$ UndangUndang Nomor 17 Tahun 2003 tentang Keuangan Negara (UU Keuangan Negara) dan Undang-Undang Nomor 27 Tahun 2009 tentang Majelis Permusyaratan Rakyat, Dewan Perwakilan Rakyat, Dewan Perwakilan Daerah, dan Dewan Perwakilan Rakyat Daerah (UU MD3) yang tidak hanya mengatur mekanisme pembahasan RAPBN di DPR pada level makro strategis, namun juga teknis sampai dengan satuan lima (unit organisasi, fungsi, program, kegiatan, dan jenis belanja) membuat beberapa elemen masyarakat sipil mengajukan pengujian undang-undang (judicial review) ke Mahkamah Konstitusi (MK). Pada Putusan No. 35/PUU-XI/2013, MK menyatakan bahwa frasa "kegiatan dan jenis belanja" adalah inkonstitusional, sehingga mekanisme pembahasan RAPBN di DPR saat ini hanya sampai dengan 'satuan tiga' (unit organisasi, fungsi, dan program).

Keterlibatan DPR dalam pembahasan RAPBN sudah dikurangi, nyatanya pada tahun 2016 ini masih ada anggota DPR yang ditangkap karena perkara korupsi anggaran. ${ }^{4}$ Karena itu persoalan yang muncul adalah sejauh mana seharusnya DPR terlibat dalam pembahasan RAPBN. Apakah model pembatasan pembahasan pada 'satuan tiga' cukup, atau sebenarnya ada yang lebih penting dan mendalam

\footnotetext{
Lihat Ronny Sautma Hotma Bako, Hak Budget Parlemen Indonesia, Jakarta: Yarsif Watampone, 2005, hlm. 3. Kasus Wisma Atlet, Kasus Hambalang, Kasus Pengadaan Al Quran, dan lain-lain menjadi contoh beberapa anggota Dewan Perwakilan Rakyat (DPR) yang terlibat korupsi dengan menyalahgunakan kewenangan hak budget yang dimiliki DPR.

$4 \quad$ Pada 13 Januari 2016 KPK menangkap Anggota DPR RI inisial DWP dalam kasus suap proyek jalan di Maluku. Lihat Tempo, "Suap Anggota DPR Damayanti Diduga Tawarkan 20 Paket Proyek", https://nasional.tempo.co/read/news/2016/01/28/063740112/suap-anggota-dpr-damayanti-didugatawarkan-20-paket-proyek, diakses 4 April 2016.
} 
mengenai bentuk keterlibatan DPR dalam pembahasan RAPBN tersebut.

Berdasarkan persoalan-persoalan tersebut, maka permasalahan yang akan dibahas dalam tulisan ini adalah sebagai berikut: pertama, bagaimana eksistensi hak budget DPR dalam sistem ketatanegaraan Indonesia apabila dikaitkan dengan teori kedaulatan rakyat; dan kedua, bagaimana keterlibatan hak budget DPR dalam pembahasan RAPBN.

\section{B. Hak Budget Parlemen}

Hak budget yang dimiliki lembaga legislatif seringkali tidak mendapat perhatian lebih dari aspek hukum khususnya hukum tata negara, karena berkaitan erat dengan persoalan persetujuan RAPBN sehingga lebih sering dilihat dari aspek ilmu ekonomi saja. Ilmu hukum tata negara sendiri lebih sering membahas dua fungsi lain DPR, yakni fungsi legislasi (berkaitan dengan kewenangan pembentukan undangundang) dan fungsi pengawasan (berkaitan dengan kewenangan mengawasi eksekutif).

Sementara itu, hak budget lembaga legislatif memiliki kedudukan yang strategis. Hamilton sebagaimana dikutip Bagir Manan ${ }^{5}$ menyebutkan bahwa cabang legislatif kuat karena menguasai pundi-pundi uang (purse). Pundi-pundi uang yang dimaksudkan adalah hak anggaran (hak budget). Sebagai pemegang hak anggaran, cabang legislatif menentukan anggaran belanja negara. Badan legislatif menentukan alokasi anggaran tahunan, bahkan dapat menolak rencana anggaran yang diajukan pemerintah. ${ }^{6}$

Karena kuatnya kewenangan badan perwakilan rakyat dalam penentuan anggaran, Kongres Amerika Serikat dapat menolak memberikan persetujuan terhadap proposal anggaran yang diajukan pemerintah. ${ }^{7}$ Akibat penolakan Kongres tersebut, pemerintahan Amerika Serikat terancam ditutup (government shutdown) karena penyelenggaraan pemerintahan tidak mungkin dijalankan tanpa adanya anggaran. $^{8}$

5 Lihat Bagir Manan, "Himpunan Tulisan Ilmiah Tentang Sistem Hukum Di Indonesia”, Dihimpun oleh Mahasiswa Program Doktor Ilmu Hukum Program Pascasarjana Universitas Padjadjaran Angkatan 2000/2001, Bandung, 2000, hlm. 2.

6 Selain itu, Hamilton juga mengatakan bahwa cabang eksekutif juga kuat karena menguasai pedang (sword). Pedang yang dimaksud adalah adanya apatur pemerintah seperti tentara, polisi, jaksa, dan lain-lain aparatur administrasi negara sebagai pelaksana yang menjalankan dan menegakkan kekuasaannya. Sementara cabang kekuasaan yang paling lemah menurut Hamilton adalah kekuasaan kehakiman (yudikatif) karena tidak memiliki pundi-pundi uang maupun pedang (aparatur) yang akan menopang pelaksanaannya. Bahkan untuk melaksanakan putusannya, kekuasaan kehakiman tergantung pada pemerintah (eksekutif), misalnya jaksa sebagai eksekutor putusan hakim (untuk perkara pidana). Lihat Bagir Manan, Ibid.

$7 \quad$ Article 1 Paragraph 7 United States Constitution (US Constitution): "All Bills for raising Revenue shall originate in the House of Representatives; but the Senate may propose or concur with Amendments as on other Bills."

$8 \quad$ A.W. Bradley dan K.D. Ewing menyebutkan bahwa "no government can exist without raising and spending money" yang menunjukkan tidak mungkin suatu pemerintahan dapat bertahan tanpa pendapatan dan belanja uang. Lihat dalam Jimly Asshiddiqie, Pokok-Pokok Hukum Tata Negara Paska Reformasi, Jakarta: Buana IImu Populer, 2008, hlm. 832-833. 
Sebagai contoh laporan Congressional Research Service, ${ }^{9}$ pemerintahan Amerika Serikat mengalami penutupan pada tahun 1996 selama 21 hari dari 16 Desember 1995 sampai dengan 6 Januari 1996 dan pada tahun 2013 selama 16 hari dari 1 Oktober 2013 sampai dengan 16 Oktober 2013. Contoh di Amerika Serikat ini memberikan pelajaran bahwa hak budget parlemen dapat digunakan sebagai sarana kontrol yang efektif terhadap kinerja pemerintahan.

Hak budget yang dimiliki parlemen berkaitan erat dengan anggaran ${ }^{10}$ negara. Anggaran negara sendiri merupakan perkiraan atau perhitungan jumlah pendapatan dan pengeluaran atau belanja yang akan dikeluarkan oleh negara. ${ }^{11} \mathrm{C}$. Goedhart menyatakan bahwa di Belanda, anggaran disebut begrooting yang berasal dari bahasa Belanda Kuno yang berarti 'mengirakan'. ${ }^{12}$ Istilah ini kemudian diambil alih oleh Undang-Undang Dasar Belanda tahun 1814. Lain halnya dengan di Inggris, anggaran disebut budget yang berasal dari bahasa Perancis bouge atau bougette yang berarti 'tas' di pinggang yang terbuat dari kulit. Kemudian kata budget ini berkembang artinya menjadi tempat surat yang terbuat dari kulit, khususnya tas kulit tersebut dipergunakan oleh Menteri Keuangan untuk menyimpan surat-surat anggaran. ${ }^{13}$

Dari sisi sejarah penggunaan istilah, yakni pada zaman Hindia Belanda, secara resmi pemerintah menggunakan anggaran dengan perkataan begrooting, perkataan ini dipergunakan baik pada zaman Regering Reglement (RR), maupun pada zaman Indische Staatregeling (IS). Selanjutnya pada zaman pendudukan Jepang berdasarkan peraturan Gunseikan tahun 2603, dipergunakan istilah 'anggaran'. ${ }^{14}$ Kemudian sejak Proklamasi tanggal 17 Agustus 1945, istilah 'Anggaran Pendapatan dan Belanja' dipakai dalam Pasal 23 Ayat (1) UUD 1945 Sebelum Perubahan yang dalam perkembangan selanjutnya secara resmi pula ditambahkan kata 'Negara', sehingga lengkapnya sampai saat ini dipergunakan istilah 'Anggaran Pendapatan dan Belanja Negara'. ${ }^{15}$ Istilah begrooting sendiri secara hukum dipakai dalam Pasal 23 Penjelasan UUD 1945 Sebelum Perubahan.

Jared N. Nagel dan Justin Murray, "Past Government Shutdowns: Key Resources", Congressional Research Service, 29 September 2015.

10 Secara etimologis, perkataan anggaran bersumber dari kata 'anggar' atau 'kira-kira' atau 'perhitungan', lihat Poerwadarminta, Kamus Umum Bahasa Indonesia, Jakarta: 1976.

1 Arifin P. Soeria Atmadja, Mekanisme Pertanggungjawaban Keuangan Negara Suatu Tinjauan Yuridis, Jakarta: Gramedia, 1986, hlm. 9. Bandingkan dengan Robert D Lee Jr. dan Ronald W. Johnson yang menyebutkan anggaran negara sebagai berikut: "In its simple form a budget is a document or a collection of documents that refer to financial condition of an organization (family, corporation, government), including information on revenues, expenditures, activities, an purposes or goolds." Lihat Robert D. Lee Jr. dan Ronald W. Johnson, Public Budgeting System, Cetakan ke-2, Tokyo: 1977, hlm. 11.

12 C. Goedhart, Garis-Garis Besar Ilmu Keuangan Negara, terjemahan Ratmoko, Jakarta: 1973, hlm. 315.

13 Ibid.

14 Arifin P. Soeria Atmadja, Op.cit., hlm. 10.

15 Ibid. 
Pada mulanya anggaran (budget) diperuntukkan untuk membiayai kepentingan rakyat suatu negara untuk satu periode dan pemerintahan yang sah, baik pemerintahan dalam bentuk monarkhi (kerajaan) ataupun bentuk republik. Pada bentuk kerajaan, semua kebutuhan kerajaan dipenuhi melalui anggaran suatu negara. Pihak kerajaan tidak memikirkan sumber penerimaan anggaran negara berasal dari mana, karena semua kebutuhan atau pengeluaran pihak kerajaan dibiayai oleh budget negara tersebut. Pada negara dalam bentuk republik, maka pemerintahan yang sah memikirkan sumber penerimaan dan sumber pengeluaran suatu negara. ${ }^{16}$

Hak budget muncul pertama kali untuk membatasi pengeluaran anggaran negara oleh raja atau pemerintahan yang ada. Sebagai contoh di Perancis, hak budget digunakan untuk membatasi anggaran negara yang digunakan untuk membiayai perang oleh Napoleon, seperti ungkapan anggota Parlemen Perancis, "the expenditures of the various departments shall be dertermined and decided...", karena kalau semua anggaran negara dipakai untuk keperluan perang, maka negara dapat dinyatakan bangkrut. Hal ini juga dialami di Inggris, ketika saat kekuasaan monarki semakin besar sehingga banyak menggunakan anggaran negara untuk kepentingan sistem monarkinya. Pemborosan-pemborosan yang dilakukan oleh Raja turunan Stuart dan kekacauan dalam administrasi keuangan mengakibatkan pecahnya revolusi Glorius Revolution of 1968 sehingga parlemen mengambil inisiatif membatasi pengeluaran negara yang diperuntukkan bagi raja ataupun yang diperuntukkan untuk peperangan. ${ }^{17}$ Dalam Artikel 4 Bill of Rights 1689, ditentukan "The levying of money for the use of the Crown without grant of Parliament was declared illegal". ${ }^{18}$ Pengeluaran keuangan negara oleh Raja tanpa persetujuan parlemen adalah sebuah tindakan yang ilegal.

Sejalan dengan menguatnya konsep demokrasi atau kedaulatan rakyat dalam bernegara, maka keterlibatan lembaga perwakilan atau parlemen dalam menentukan anggaran negara semakin memperoleh basis pembenaran secara ilmiah. Dalam konteks itu, hak budget parlemen merupakan perwujudan fungsi otorisasi berupa pemberian persetujuan anggaran negara yang diajukan pemerintah. Rene Stourm menyatakan, bahwa: ${ }^{19}$

"The constitutional right which a nation possesses to authorize public revenues and expenditures does not originate from the fact the members of nation contribute the payments. This right is based on loftieridea; the idea of souvereignty".

16 Ronny Sautma Hotma Bako, Op.cit., hlm. 126.

17 A. Rivai, Hak Budget Dewan Perwakilan Rakyat dan Keuangan Daerah Otonom, Bandung: NV Nix \& Co, 1951, hlm. 13.

18 Lihat Jimly Asshiddiqie, Op.cit., hlm. 833.

19 Lihat Arifin P. Soeria Atmadja, Keuangan Publik dalam Perspektif Hukum, Teori, Krtik dan Praktik, Jakarta: Rajawali Pers, 2009, hlm. 54. 
Pendapat Rene Stourm tersebut memberikan penegasan mengenai esensi hak budget parlemen dalam memberikan otorisasi pendapatan negara dan pembelanjaannya; bukan karena rakyat berkontribusi membayarkan pajak saja, melainkan merupakan ide yang lebih mulia dari itu, yakni berbicara mengenai kedaulatan. ${ }^{20}$ Apabila kedaulatan ada di tangan raja, maka rajalah yang berhak sepenuhnya menentukan anggaran negara. Namun apabila suatu negara menganut paham demokrasi atau kedaulatan rakyat, maka rakyatlah yang berhak sepenuhnya menentukan anggaran negara tersebut. Dalam konteks ini, pelembagaan parlemen sebagai perpanjangan tangan rakyat dalam konteks demokrasi tidak langsung, maka parlemenlah atas nama rakyat berhak untuk menentukan anggaran negara.

Karena itu menurut Arifin P. Soeria Atmadja, persetujuan parlemen terhadap usul anggaran negara dari pemerintah merupakan kuasa 'machtiging' dan bukan merupakan 'consent'. ${ }^{21}$ Arifin menyitir pendapat Simons bahwa anggaran negara merupakan machtiging dari parlemen: ${ }^{22}$

"Elk begrotingshoofdtuk world bij afzonderlijke wet vasgesteld. De wetsontwerpen zijn voor de Regeering middle tot de verkrijging van de autorisatie van de volksvertegenwoordiging om uitgeven tot bepaalde maxima te doen, daardoor soms ook om maatregelen te troffen welke uitgaven eisen."

Dengan demikian, titik berat tujuan anggaran negara adalah mengenai 'autorisatie' dari 'volksvertegenwoordiging' kepada pemerintah untuk mengadakan pengeluaran atau pembiayaan sejumlah maksimal tertentu anggaran negara. Anggaran negara sebagai otorisasi atau pemberian kuasa kemudian menimbulkan kewajiban untuk mempertanggungjawabkan terhadap kuasa yang telah diberikan. Maka dari itu, dalam hak budget parlemen tidak hanya sebatas memberikan persetujuan terhadap proposal anggaran negara, melainkan juga pengawasan terhadap pelaksanaan anggaran negara serta meminta pertanggungjawaban dalam pelaksanaan anggaran negara tersebut. Hal ini berbeda dengan 'consent' yang hanya memiliki makna persetujuan secara sukarela. ${ }^{23}$

\footnotetext{
20 Kedaulatan yang dalam bahasa Inggrisnya sovereignty berasal dari basaha latin superanus, berkaitan dengan ide kekuasaan tertinggi dalam urusan bernegara.

21 Arifin P. Soeria Atmadja, Keuangan Publik..., Op.cit., hlm. 55. hal Hal mengenai '“consent'” diutarakan oleh A. Hamid S. Attamimi, dalam Majalah Hukum dan Pembangunan No. 4 Tahun X Juli 1980, dengan judul "UndangUndang Perhitungan Anggaran Negara. Perlukah Itu?"

22 Ibid., hlm. 56.

23 'Consent' menurut Black's Laws Dictionary berupa: "CONSENT. A concurrence of wills. Voluntarily yielding the will to the proposition of another; acquiescence or compliance therewith" (Sebuah persetujuan kehendak. Sukarela menghasilkan keinginan untuk proposisi lain; persetujuan atau kepatuhan dengannya - Penulis) Lihat Henry Campbel Blacks, Black's Law Dictionary Fourth Edition, St. Paul Minn: West Publishing Co, 1968, hlm. 377.
} 
Selain itu, sejalan pula dengan munculnya ajaran pemisahan kekuasaan dari Montesquieu; ${ }^{24}$ anggaran negara yang semula hanya merupakan masalah 'tata usaha' atau 'administrasi' semata, telah berubah menjadi persoalan pembentukan undang-undang. ${ }^{25}$ Disitulah 'hak budget' atau budgetrecht muncul. Karena itu penyusunan suatu anggaran, khususnya anggaran negara, perlu diatur dalam peraturan perundang-undangan. Hal ini untuk menjadi barometer bersama ketika menyusun suatu rancangan anggaran negara. Maka peraturan perundangundangan merupakan aspek formil dalam penyusunan rancangan anggaran negara, sedangkan aspek materil dari anggaran negara adalah mengenai hal apa saja yang perlu diatur dalam segi pengeluaran negara dan penerimaan negara. ${ }^{26}$

Kaitan antara hak budget dalam pembentukan undang-undang juga sejalan dengan pendapat Jimly Asshiddiqie yang menyebutkan fungsi anggaran (hak budget) masuk kedalam fungsi legislasi karena pada pokoknya selalu dituangkan dalam bentuk undang-undang. ${ }^{27}$ Selain itu, menurut Jimly fungsi anggaran juga masuk dalam fungsi pengawasan karena parlemen pula yang melakukan pengawasan terhadap anggaran negara yang terbagi dalam dua bentuk, yakni pengawasan terhadap penganggaran dan belanja negara (control of budgeting) serta pengawasan terhadap pelaksanaan anggaran dan belanja negara (control of budget implementation). ${ }^{28}$

Atas dasar itu, Jimly Asshiddiqie mendefinisikan hak budget sebagai hak konstitusional yang dimiliki oleh parlemen untuk menentukan pendapatan, pembelanjaan negara, dan perpajakan serta melakukan pengawasan umum terhadap anggaran dan pendapatan perbelanjaan negara. Sejalan dengan itu, Jese Burkhead menyatakan bahwa di Amerika Serikat, proses budget sebagai cara penggunaan anggaran negara yang akan digunakan untuk berbagai keperluan pada umumnya oleh pemerintah yang ditetapkan oleh Kongres untuk tahun fiskal yang akan datang. Adapun proses budget terdiri dari: (1) formulation budget; (2) enactment of the budget; (3) execution of budget; dan (4) postaudit of the budget.

Dari uraian di atas maka dapat disimpulkan bahwa kedudukan hak budget parlemen dalam sebuah negara yang berkedaulatan rakyat memiliki tingkat urgensi atau keperluan yang tinggi karena berkaitan erat dengan ide kedaulatan rakyat. Rakyatlah yang memiliki pundi-pundi (purse), sehingga penggunaan uang tersebut harus dengan persetujuan rakyat yang diwakili oleh parlemen.

Lebih lanjut hak budget parlemen dalam bentuk persetujuan terhadap proposal anggaran dan belanja yang diajukan pemerintah, diformalkan dalam bentuk

\footnotetext{
Montesquieu menelurkan pemisahan kekuasaan menjadi tiga bagian, yakni eksekutif, legislastif, dan yudikatif. Arifin P. Soeria Atmadja, Mekanisme Pertanggungjawaban..., Op.cit., hlm. 15.

Ronny Sautma Hotma Bako, Op.cit., hlm. 31.

Jimly Asshiddiqie, Op.cit., hlm. 160.

Ibid., hlm. 163.
} 
undang-undang yang menunjukkan tingkatan atau jenis peraturan tinggi yang harus memperoleh persetujuan lembaga perwakilan. Karenanya anggaran yang belum disetujui oleh parlemen menjadi ilegal apabila dipergunakan oleh eksekutif. Di dalam hak budget tersebut terdapat otorisasi dari rakyat, sehingga memberikan implikasi adanya pengawasan dan pertanggungjawaban terhadap pelaksanaan dan penggunaan anggaran tersebut.

\section{Hak Budget DPR}

1. Hak Budget DPR Menurut UUD 1945 Sebelum Perubahan

Sebelum Perubahan UUD 1945, hanya ada satu ketentuan yang menunjukkan posisi hak budget Parlemen Indonesia. Tepatnya terdapat pada Pasal 23 Ayat (1) yang disebutkan bahwa:

"Anggaran pendapatan dan belanja ditetapkan tiap-tiap tahun dengan undang-undang. Apabila Dewan Perwakilan Rakyat tidak menyetujui anggaran yang diusulkan pemerintah, maka pemerintah menjalankan anggaran tahun yang lalu."

Pasal ini menunjukkan bentuk hak budget DPR adalah pemberian persetujuan atau tidak persetujuan terhadap anggaran pendapatan dan belanja negara yang setiap tahun diusulkan pemerintah. Sebagaimana disebutkan Yamin yang mengatakan bahwa: "DPR kita tiap-tiap tahun menetapkan bersama dengan pemerintah anggaran penghasilan dan belanja, itulah yang dinamakan begrootingsrecht" ${ }^{29} \mathrm{Hal}$ menarik dari pasal ini adalah ketentuan mengenai kondisi ketika DPR menolak atau tidak menyetujui anggaran yang diusulkan oleh pemerintah, maka pemerintah menjalankan anggaran tahun yang lalu. Itu artinya, hak budget DPR tidak akan membuat government shutdown seperti yang terjadi di Amerika Serikat.

Munculnya ketentuan menggunakan anggaran tahun yang lalu jika anggaran tidak disetujui DPR sendiri dapat ditelisik berasal dari pertanyaan Ratulangi dalam Rapat Panitia Persiapan Kemerdekaan Indonesia (PPKI) pada tanggal 18 Agustus 1945 sebagai berikut:

"Satu hal jang saja tidak djumpai dalam grondwet, jaitu peraturan tentang kedjadian jang mungkin ada dikemudian hari. Apabila suatu begrooting, satu anggaran belandja ditolak oleh Badan Perwakilan Rakjat, bisa kedjadian itu mengadakan konflik. Itu harus diurus, dan tentu dengan djalan permusjawaratan; tetapi mungkin djuga tidak dapat persetudjuan. Karena itu menurut perasaan saja, Paduka Tuan

29 Muhammad Yamin, Naskah-Persiapan Undang-Undang Dasar 1945, Jilid Pertama, Cetakan Kedua, Jakarta: Yayasan Prapanca, 1971, hlm. 311. 
Ketua, harus dikemukakan sekarang djuga djika barangkali mungkin, suatu fatsal, jang mengurus hal itu." 30

Atas pertanyaan tersebut, Supomo memberikan usul:

"Saja usulkan, supaja pasal 23 ajat ke-1, itu dengan ketentuan, bahwa apabila Dewan Perwakilan Rakjat tidak menjetudjui anggaran jang diusulkan oleh Pemerintah, maka akan didjalankan anggaran untuk tahun jang lalu. Umpamanja tidak diterima, haruslah ada djalannja, sebab negara harus berdjalan terus." 31

Dalam konteks ini, kita harus mengakui para founding fathers Indonesia memiliki kemampuan dan cara pandang kedepan yang visioner serta solutif terhadap kemungkinan problem ketatanegaraan yang sangat mungkin muncul. Dengan demikian kemungkinan deadlock yang membuat pemerintahan terganggu dapat langsung diatasi.

Selain itu, yang menarik dari Pasal 23 Ayat 1 ini adalah bunyi penjelasannya sebagai berikut:

"Ayat I memuat hak begrooting Dewan Perwakilan Rakyat. Hak begrooting atau hak budget ini menempatkan DPR RI pada posisi yang kuat, seolah-olah menjelaskan betapa berkedaulatannya rakyat sungguh-sungguh benar dengan perantara DPR sebagai utusannya. Hal ini berbeda dengan model negara fasisme yang otoritarianisme sangat kuat, di mana anggaran itu ditetapkan semata-mata hanya dari pemerintah. Tetapi dalam negara demokrasi yang berkedaulatan rakyat, anggaran negara ditetapkan dengan undang-undang. Artinya dengan persetujuan Dewan Perwakilan Rakyat. Betapa caranya rakyat sebagai bangsa akan hidup dan dari mana didapatnya belanja buat hidup, harus ditetapkan oleh rakyat sendiri, dengan perantaraan dewan perwakilannya. Rakyat menentukan nasibnya sendiri, karena itu juga cara hidupnya. Pasal 23 menyatakan bahwa dalam hal menetapkan pendapatan dan belanja, kedudukan Dewan Perwakilan Rakyat lebih kuat daripada kedudukan pemerintah. Ini tanda kedaulatan rakyat."

Penjelasan Pasal 23 Ayat 1 tersebut memberikan beberapa implikasi. Pertama, bahwa dalam sistem ketatanegaraan Indonesia, DPR memiliki hak budget atau hak begrooting. Kedua, hak budget DPR tersebut menempatkan DPR pada posisi yang lebih kuat dibandingkan dengan pemerintah. Ketiga, hak budget DPR tersebut merupakan bentuk berdaulatnya rakyat sebagai jalan hidup bernegara. Jika dikaitkan dengan konsep hak budget parlemen sebagai wujud kedaulatan rakyat

$30 \quad$ Ibid., hlm. 412.

$31 \quad$ lbid., hlm. 413. 
sebagai mana telah diulas sebelumnya, maka para founding fathers Indonesia lagilagi memberikan bukti kemampuan bernegaranya yang handal dalam meletakkan dasar pijakan yang kuat ketika menempatkan hak budget DPR sebagai bentuk berdaulatnya rakyat dan bukan sekedar instrumen ekonomi semata.

Walaupun posisi hak budget DPR secara konstitusional kuat, namun dalam praktiknya (selama UUD Tahun 1945 Sebelum Perubahan) hanya satu kali RAPBN yang diajukan pemerintah ditolak oleh DPR; yakni ketika RAPBN yang diajukan Presiden Soekarno di tahun 1960 ditolak DPR. ${ }^{32}$ Selebihnya ketika Presiden Soeharto memimpin, hak budget DPR tidak pernah digunakan untuk menolak RAPBN.

\section{Hak Budget DPR Menurut UUD RIS dan UUDS 1950}

Sebagai sebuah pelajaran ketatanegaraan, perlu juga melihat hak budget DPR dalam dua konstitusi yang pernah berlaku di Indonesia yakni Konstitusi Republik Indonesia Serikat (Konstitusi RIS) dan Undang-Undang Dasar Sementara 1950 (UUDS 1950). Berkaitan dengan hak budget DPR dalam Konstitusi RIS diatur dalam Pasal 168:

(1) Usul undang-undang penetapan anggaran umum oleh Pemerintah dimajukan kepada Dewan Perwakilan Rakyat sebelum permulaan masa yang berkenaan dengan anggaran itu. Masa itu tidak boleh lebih dari dua tahun.

(2) Usul undang-undang pengubahan anggaran umum, tiap-tiap kali jika perlu dimajukan Pemerintah kepada Dewan Perwakilan Rakyat.

(3) Usul undang-undang dimaksud dalam kedua ayat yang lalu dirundingkan pula oleh Senat atas dasar ketentuan-ketentuan Bagian II Bab ini.

Lebih lanjut juga diatur dalam Pasal 170 Konstitusi RIS:

"Pengeluaran dan penerimaan Republik Indonesia Serikat ditanggungjawabkan kepada Dewan Perwakilan Rakyat, sambil memajukan perhitungan yang disahkan Dewan Pengawas Keuangan, menurut aturan-aturan yang diberikan dengan undang-undang federal."

Sementara itu, dalam UUDS 1950, hak budget DPR disebutkan Pasal 114:

(1) Usul undang-undang penetapan anggaran umum oleh Pemerintah dimajukan kepada Dewan Perwakilan Rakyat sebelum permulaan masa yang berkenaan dengan anggaran itu. Masa itu tidak boleh lebih dari dua tahun.

(2) Usul undang-undang pengubah anggaran umum, tiap-tiap kali jika dimajukan Pemerintah kepada Dewan Perwakilan Rakyat.

Kemudian Pasal 116 UUDS 1950:

Pengeluaran dan penerimaan Republik Indonesia dipertanggungjawabkan kepada Dewan Perwakilan Rakyat, sambil memajukan

32 Akibat penolakan tersebut, DPR dibubarkan oleh Presiden Soekarno karena dianggap tidak sesuai dengan manifesto politik demokrasi terpimpin. 
perhitungan yang disahkan oleh Dewan Pengawas Keuangan, menurut aturan-aturan yang diberikan dengan undang-undang.

Dari dua konstitusi tersebut, baik Konstitusi RIS maupun UUDS 1950, terdapat beberapa catatan, pertama terkait istilah APBN yang disebut dengan anggaran umum. Kedua, adanya mekanisme perubahan terhadap anggaran umum atau sering disebut dengan APBN-Perubahan. Ketiga, terkait dengan hak budget DPR diposisikan sebagai yang membahas proposal anggaran dari pemerintah. Khusus di Konstitusi RIS, pembahasan tersebut juga dirundingkan dengan Senat. Hal tersebut wajar karena bentuk negara ketika itu federal. Keempat, adanya penegasan bahwa anggaran umum tersebut dipertanggungjawabkan kepada DPR dengan pengesahan dari Dewan Pengawas Keuangan (saat ini adalah Badan Pemeriksa Keuangan / BPK).

\section{Hak Budget DPR RI Menurut UUD 1945 Setelah Perubahan}

Pasca Perubahan UUD 1945, disebutkan dalam Aturan Tambahan II bahwa dengan ditetapkannya Perubahan UUD 1945 ini, maka UUD 1945 terdiri atas pembukaan dan pasal-pasal. Dengan demikian maka penjelasan UUD 1945 sudah tidak memiliki kekuatan hukum lagi. Mekanisme pembahasan APBN yang melibatkan DPR Pasca Perubahan UUD 1945 terdapat dalam Pasal 23 menyebutkan

(1) Anggaran pendapatan dan belanja negara sebagai wujud dari pengelolaan keuangan negara ditetapkan setiap tahun dengan undang-undang dan dilaksanakan secara terbuka dan bertanggungjawab untuk sebesar-besarnya kemakmuran rakyat.

(2) Rancangan undang-undang anggaran pendapatan dan belanja negara diajukan oleh Presiden untuk dibahas bersama Dewan Perwakilan Rakyat dengan memperhatikan pertimbangan Dewan Perwakilan Daerah.

(3) Apabila Dewan Perwakilan Rakyat tidak menyetujui rancangan anggaran pendapatan dan belanja negara yang diusulkan oleh Presiden, Pemerintah menjalankan Anggaran Pendapatan dan Belanja Negara tahun yang lalu.

Dalam ketentuan Pasal 23 tersebut, tidak disebutkan istilah 'hak budget DPR'. Karena itu perlu dipertanyakan apakah hak budget DPR menjadi hilang eksistensinya atau tidak. Berdasarkan penelitian penulis pada tahun 2013, yang mendasarkan adanya penegasan fungsi anggaran dalam Pasal 20A UUD 1945 Setelah Perubahan, serta rumusan Pasal 23 terkait keterlibatan DPR dalam pembahasan RAPBN, maka eksistensi hak budget DPR tidaklah hilang, melainkan tetap ada sebagai kekuasaan inheren.

Analisis tersebut menggunakan interpretasi sistematis ${ }^{33}$ bahwa ketentuan Pasal 23 yang menyebut keterlibatan DPR dalam pembahasan RAPBN tidaklah

33 Intepretasi sistematis menyuruh kita harus membaca undang-undang dalam keseluruhannya, kita tidak boleh mengeluarkan suatu ketentuan lepas dari keseluruhannya, tetapi kita harus meninjaunya dalam hubungannya dengan ketentuan sejenis. Lihat Sudikno Mertokusumo dan A. Pitlo, Bab-Bab Tentang Penemuan Hukum, Bandung: Citra Aditya Bakti, 1993, hlm. 60. 
berdiri sendiri, melainkan harus merujuk pada Pasal 20A yang menyebutkan "Dewan Perwakilan Rakyat memiliki fungsi legislasi, fungsi anggaran dan fungsi pengawasan" (cetak tebal oleh Penulis). Frasa DPR memiliki fungsi anggaran menunjukkan secara tegas bahwa DPR sebagai representasi rakyat berperan dalam penting dalam hal hal pembuatan, persetujuan, pengawasan, dan pertanggungjawaban anggaran negara.

Selain itu juga digunakan penafsiran historis undang-undang (wethistorisch) ${ }^{34}$ dengan cara menelusuri latar belakang pembahasan Perubahan UUD 1945. Dalam konteks hak budget DPR diperoleh bahwa terdapat perdebatan-perdebatan khususnya berkaitan dengan perubahan materi tentang DPR. Salah satu hal yang paling penting adalah kesepakatan penguatan derajat kedaulatan rakyat berupa penegasan dianutnya cita demokrasi ${ }^{35}$ dan menyempurnakan dasar penyelenggaraan negara secara demokratis dan modern. ${ }^{36}$ Dengan demikian, maka menjadi relevan jika kedudukan hak budget DPR dalam kaitan menjalankan fungsi anggaran DPR secara inheren terkandung didalamnya.

Penguatan derajat kedaulatan rakyat juga sejalan dengan dimasukkannya Dewan Perwakilan Daerah (DPD) sebagai salah satu lembaga perwakilan yang memberikan pertimbangan dalam pembahasan APBN di DPR yang diatur dalam Pasal 23 Ayat (2) dan Pasal 22D Ayat (2).

Adapun Pada Pasal 22 D Ayat (2) disebutkan:

Dewan Perwakilan Daerah ..., serta memberikan pertimbangan kepada

Dewan Perwakilan Rakyat atas rancangan undang-undang anggararan pendapatan dan belanja negara, ...

Kurang tepat jika setelah perubahan UUD 1945, hak budget DPR menjadi hilang eksistensinya. Dari rumusan pasal-pasal tersebut juga diperoleh tiga hal pokok, yaitu: (1) Presiden merupakan satu-satunya pihak yang berwenang mengajukan rancangan APBN; (2) DPR merupakan lembaga parlemen yang membahas rancangan $A P B N$ tersebut dengan pertimbangan DPD; dan (3) rancangan APBN

34 Sudikno Mertokusumo dan A. Pitlo membedakan penafsiran historis menjadi dua, yakni penafsiran historis undang-undang (wethistorisch) dan penafsiran historis hukum (rechtshistorisch). Penafsiran historis undangundang yaitu dengan mempelajari sejarah naskah undang-undang, tinjauan yang diberikan parlemen oleh menteri, atau anggota parlemen tentang rancangan undang-undang. Sementara penafsiran historis hukum berkaitan dengan terjadinya dan timbulnya suatu lembaga hukum secara khusus, kebutuhan-kebutuhan manalah yang dipenuhi pada saat lembaga hukum itu dilahirkan dalam kehidupan bersama, bagaimanakah berkembangnya selama bertahun-tahun atau abad-abad ini, dan apa saja yang mempengaruhinya. Lihat Sudikno dan A. Pitlo, Ibid., hlm. 63-64.

35 Jimly Asshiddiqie, "Struktur Ketatanegaraan Indonesia Setelah Amandemen Keempat UUD 1945", Makalah disampaikan pada Seminar Pembangunan Hukum Nasional VIII, Denpasar, Bali, 14-18 Juli 2003, hlm. 1.

36 Majelis Permusyawaratan Rakyat (MPR), Panduan Pemasyarakatan Undang-Undang Dasar Negara Republik Indonesia Tahun 1945, Jakarta: Sekretariat Jenderal MPR RI, 2005, hlm. 8-9. 
tidak boleh tanpa persetujuan DPR. Apabila DPR tidak menyetujui, maka Pemerintah menjalankan APBN tahun lalu. Di sini terlihat DPR memiliki kewenangan yang besar dalam pemberian persetujuan RAPBN, terutama jika dibandingkan dengan DPD.

Hak budget secara inheren terdapat di DPR sebagai lembaga perwakilan rakyat, namun masih terdapat persoalan atas Perubahan UUD 1945, khususnya Pasal 23 Ayat (1) yang disebutkan bahwa, "APBN sebagai wujud pengelolaan keuangan negara".. Sebagai contoh kritik dari Arifin P. Soeria Atmadja yang menyebut ketentuan tersebut hanya retorika dangkal dan bombastis yang tidak bermakna dari sudut filosofi anggaran. ${ }^{37}$ Akibat definisi tersebut APBN hanya bermakna akuntansi, sehingga konsepsi hak budget DPR sebagai bentuk kedaulatan rakyat menjadi tergerus. Dengan demikian, DPR yang awalnya sebagai pihak yang lebih tinggi karena memberikan kuasa dalam bentuk otorisasi seringkali dikalahkan oleh hitunghitungan akuntansi yang jauh dari kedaulatan rakyat. Karena itu, "APBN sebagai wujud pengelolaan keuangan negara", semestinya diganti dengan "APBN sebagai wujud kedaulatan rakyat dalam pengelolaan keuangan negara".

\section{Hak Budget DPR Dalam UU Keuangan Negara dan UU MD3}

Ketentuan hak budget DPR terhadap RAPBN yang diajukan Presiden diatur secara organik dalam UU Keuangan Negara dan UU MD3. Terdapat 5 Tahapan Pembahasan APBN, khususnya yang melibatkan DPR, antara lain:

(1) Tahap pembicaraan pendahuluan penyusunan APBN;

(2) Tahap pembahasan RUU APBN;

(3) Tahap Laporan Realisasi Semester I dan Prognosis Semester II;

(4) Tahap pembahasan APBN Perubahan (APBN-P); dan

(5) Tahap Pertanggungjawaban atas pelaksanaan APBN.

Dalam rangkaian hak budget DPR, maka akan dihasilkan tiga jenis undangundang, yaitu undang-undang APBN, undang-undang APBN Perubahan, dan undang-undang pertanggungjawaban atas pelaksanaan APBN. Ketiga undangundang tersebut merupakan satu keterkaitan terhadap sebuah anggaran pendapatan dan belanja negara dalam satu tahun anggaran.

Hal menarik dari kedua undang-undang tersebut adalah keterlibatan DPR dalam pembahasan RAPBN. Pada Pasal 15 Ayat (5) UU Keuangan Negara ditentukan bahwa "APBN yang disetujui oleh DPR terinci sampai dengan unit organisasi, fungsi, program, kegiatan dan jenis belanja". Hal yang sama juga diatur dalam UU MD3 sebelum keluarnya Putusan MK No. 35/PUU-XI/2013. Setelah putusan tersebut, maka UU MD3 terbaru (Undang-Undang Nomor 17 Tahun 2014 tentang MPR, DPR, DPD, DPRD), mengatur keterlibatan DPR dalam pembahasan RAPBN hanya terinci sampai dengan unit organisasi, fungsi, dan program saja.

37 Arifin P. Soeria Atmadja, Keuangan Publik..., Op.cit., hlm. 73. 
Mekanisme pembahasan dari unit organisasi, fungsi, program, kegiatan, dan jenis belanja menunjukkan kekuasaan yang 'powerful' dari DPR dalam menentukan RAPBN. Hal ini menunjukkan keterlibatan DPR dalam pembahasan RAPBN sampai dengan 'sangat' mendetail, sehingga sangat mungkin menimbulkan beragam persoalan.

\section{Putusan MK No. 35/PUU-XI/2013 Terhadap Hak Budget DPR}

Pada 22 Mei 2014, MK memutus pengujian UU Keuangan Negara dan UU MD3 melalui Putusan MK No. 35/PUU-XI/2013 terhadap Hak Budget DPR. Salah satu dasar pengujian kedua undang-undang tersebut adalah terjadinya penyalahgunaan kewenangan terhadap fungsi anggaran DPR yang kemudian menjerat beberapa anggota DPR dalam perkara korupsi. Hal tersebut diakibatkan hak budget DPR yang diatur dalam kedua undang-undang tersebut terlalu memberikan kewenangan yang luas, mendetail, dan bersifat teknis. Pada Pasal 15 Ayat (5) UU Keuangan Negara maupun Pasal 107 Ayat (1) huruf c, Pasal 156 huruf c angka 2 huruf (c), Pasal 157 ayat (1) huruf c, Pasal 159 ayat (5) UUD MD3; disebutkan bahwa keterlibatan DPR dalam pembahasan RAPBN adalah mulai dari unit organisasi, fungsi, program, kegiatan, dan jenis belanja.

Dalam putusannya, MK menyatakan berkaitan dengan penetapan anggaran dalam bentuk APBN, fungsi anggaran DPR tidak terlalu jauh ikut membuat perencanaan anggaran akan tetapi hanya memberikan persetujuan atas rencana yang diajukan oleh Presiden. Hal ini karena adanya prinsip pembagian kekuasaan dan checks and balances tersebut mengakibatkan kewenangan DPR dibatasi dan ditegaskan pada fungsi pengawasan jalannya pemerintahan; sedangkan fungsi perencanaan adalah termasuk pada fungsi eksekutif, yaitu merencanakan dan melaksanakan atau mengeksekusi jalannya pemerintahan.

Menurut MK, pembahasan terinci sampai pada tingkat kegiatan dan jenis belanja kementerian/lembaga dapat menimbulkan persoalan konstitusional apabila dilihat dari kewenangan konstitusional DPR dalam menjalankan fungsi anggaran. Persoalan tersebut bersumber dari keikutsertaan DPR dalam membahas RAPBN yang terperinci sampai dengan kegiatan dan jenis belanja. Hal tersebut tidak sesuai dengan fungsi dan kewenangan DPR sebagai lembaga perwakilan yang seharusnya tidak ikut menentukan perencanaan yang sifatnya sangat rinci tersebut. Adapun kegiatan dan jenis belanja merupakan urusan penyelenggaraan pemerintahan negara yang dilaksanakan oleh Presiden sebagai perencana dan pelaksana APBN.

Terdapat banyak pihak yang mengapresiasi putusan MK tersebut. Bahkan menurut Yutirsa Yunus dan Reza Faraby, ${ }^{38}$ Putusan MK No. 35/PUU-XI/2013 yang

38 Lihat Yutirsa Yunus dan Reza Faraby, "Reduksi Fungsi Anggaran DPR Dalam Kerangka Checks and Balances", Jurnal Konstitusi, Vol. 7 No. 2 Agustus 2014, hlm. 199. 
mereduksi fungsi anggaran dapat dianggap putusan penting (landmark decision), karena merombak kembali tatanan fungsi antar lembaga negara dalam menjalankan fungsi anggaran. Sejalan dengan itu, Dian Puji N. Simatupang ${ }^{39}$ menganggap Putusan MK Nomor 35/PUU-XI/2013 adalah tepat, karena telah mereposisi hak budget DPR guna mengakhiri dominasi rasionalitas politis dalam persetujuan RAPBN yang mengesampingkan rasionalitas teknokratis.

Menurut Dian, Pasal 23 UUD 1945 sebagai dasar konstitusional hak budget DPR sebenarnya secara harfiah telah membatasi hak budget pada menerima atau menolak RAPBN yang diajukan pemerintah. Pembatasan hak budget tersebut intinya terletak pada fokus DPR untuk menilai dengan alasan legitimitasi atau kemanfaatan publik terhadap APBN dibandingkan penilaian teknis. Dengan demikian, DPR memfokuskan pada strategi anggaran negara yang sesuai dengan kebutuhan rakyat, bukan pada teknis angka-angka anggaran. Dengan memosisikan hak budget sebatas menerima dan menolak RAPBN yang diajukan pemerintah dengan dua alasan, yakni: pertama, RAPBN tidak sesuai dengan prioritas fungsi dan program yang telah direncanakan pemerintah dalam dokumen perencanaan; dan kedua, RAPBN tidak memiliki alasan kemanfaatan (legitimasi) bagi kualitas penyelenggaraan pemerintahan secara umum dan pelayanan publik.

Lebih lanjut Dian menyebutkan adanya reposisi hak budget tersebut akan menghindarkan penggunaan wewenang atau mentransaksikan pengaruh DPR pada hal-hal bersifat mikroteknis atau mikropraktis. Sebab, kondisi demikian akan menyebabkan DPR berkutat pada perhitungan transaksi politis atau angka-angka anggaran dengan motivasi di luar kepentingan umum yang seharusnya dilindungi dan di luar rasionalitas dokumen perencanaan pembangunan yang ditetapkan sebelumnya.

Putusan MK No. 35/PUU-XI/2013, walau mengundang banyak apresiasi, tidak lantas langsung menghilangkan praktik memperjualbelikan pengaruh di DPR. Sebagaimana sempat disinggung, pada awal tahun 2016 ini, Komisi Pemberantas Korupsi (KPK) kembali menangkap anggota DPR yang menerima suap dalam pengurusan rencana anggaran pembangunan jalan Kementerian Pekerjaan Umum dan Perumahan Rakyat (PUPR) di Maluku. Karena itu, walaupun frasa "kegiatan dan jenis belanja" telah dihilangkan, praktik koruptif memperdagangkan hak budget DPR masih saja terjadi.

Selain itu, terdapat persoalan krusial yang sebenarnya muncul dari pembahasan RAPBN di DPR. Ibrahim Zuhdi Badoh, Yuna Farhan, dan Ridaya Laodengkowe ${ }^{40}$ menyebutkan bahwa kualitas budget proposal dari eksekutif sering

\footnotetext{
Dian Puji N. Simatupang, “Reposisi Hak Budget DPR”, Opini di Harian Kompas, Rabu, 18 Juni 2014.

40 Ibrahim Zuhdi Badoh, Yuna Farhan, dan Ridaya Laodengkowe, Politik dan Birokrasi Anggaran Indonesia, dalam buku Anggaran Pro Kaum Miskin, Sebuah Upaya Menyejahterakan Masyarakat, Jakarta: Pustaka LP3ES, 2009, hlm. 140.
} 
kali tidak memenuhi harapan karena kuatnya pendekatan inkremental dalam birokrasi anggaran. Pendekatan inkremental maksudnya adalah adanya perilaku birokrasi untuk selalu mempertahankan pola alokasi anggaran seperti tahun sebelumnya, tanpa mempertimbangkan relevansinya dengan isu yang berkembang di masyarakat. Bahkan Dian Puji N. Simatupang dalam disertasinya pun sempat menyinggungnya pada pembahasan yang sama, dengan menyebutkan akibat dari ketidakmampuan APBN menerapkan prinsip kepemerintahan yang baik sebagai wujud keuangan negara adalah "inkrementalisme dan rutinisme". ${ }^{41}$

Kedua pendapat tersebut sebenarnya menunjukkan bahwa kualitas proposal RAPBN sering kali bermasalah dan sayangnya masalah tersebut tidak mampu diperbaiki oleh DPR dalam pembahasan, karena bahkan DPR ikut terlibat dalam "inkrementalisme dan rutinisme" tersebut. Untuk itu, peran hak budget DPR khususnya berkaitan dengan teknis dan detil anggaran yang menyangkut unit organisasi, fungsi, program, kegiatan, dan jenis belanja semestinya mampu mengoreksi dan memperbaiki program maupun kegiatan yang mata anggarannya kemungkinan sama atau terjadi duplikasi, atau tidak sesuai dengan kebutuhan dasar masyarakat. Selain itu, pembahasan yang mendetil juga diharapkan mampu membuka keran transparansi dalam pembahasan RAPBN sehingga elemen masyarakat khususnya masyarakat bawah (miskin) dapat memperjuangkan hakhaknya.

Pengalaman sebelum keluarnya Putusan MK No. 35/PUU-XI/2013 menunjukan bahwa walaupun pembahasan RAPBN itu sampai mendetil sampai kegiatan dan jenis belanja, namun tingkat transparansinya masih rendah. Bahkan kecenderungan pembahasan RAPBN seringkali dilakukan secara tertutup. Akibatnya inkrementalisme dan rutinisme terus berulang. Hal inilah yang menjadi persoalan, jika mendetil saja tingkat transparansi rendah membuat APBN belum maksimal untuk sebesar-besarnya kemakmuran rakyat, lalu bagaimana jika pembahasannya tidak mendetil.

Contoh yang cukup ironis adalah laporan riset yang dikeluarkan oleh National Democratic Institute (NDI) for International Affairs tahun 2005, keluhan yang paling sering diutarakan anggota DPR, tercatat sebesar $89 \%$, adalah tidak mengetahui rincian anggaran operasional DPR. ${ }^{42}$ Pertanyaannya, jika anggota DPR sendiri sulit mendapatkan informasi mengenai anggarannya, bagaimana dengan masyarakat,

Dian Puji N. Simatupang, Paradoks Rasionalitas Perluasan Ruang Lingkup Keuangan Negara dan Implikasinya Terhadap Kinerja Keuangan Pemerintah, Jakarta: Badan Penerbit FH UI, 2011, hlm. 348. Pengertian inkrementalisme adalah upaya melakukan perubahan selangkah demi selangkah yang cenderung tambal sulam, dan rutinisme adalah upaya memelihara pola kegiatan reguler yang sudah baku.

42 Lihat Riris Katharina dan Poltak Partogi Nainggolan, Menciptakan DPR dan Sistem Pendukung Parlemen yang Mendukung Anggaran Pro-kaum Miskin, dalam buku Anggaran Pro Kaum Miskin, Sebuah Upaya Menyejahterakan Masyarakat yang disusun oleh Yuna Farhan (ed), Jakarta: Pustaka LP3ES, 2009, hlm. 279. 
khususnya rakyat biasa (miskin). Bagaimana pula jika pembahasannya tidak mendetil, karena tentunya juga semakin berpengaruh terhadap kualitas hasil pembahasan RAPBN.

Dari situlah timbul persoalan. Apabila terlalu detil dan teknis, di satu sisi membuka keran kemungkinan perdagangan pengaruh dalam pembahasan RAPBN, di lain sisi proposal anggaran RAPBN pemerintah pun belum tentu baik sehingga dibutuhkan koreksi. Karena itu, Putusan MK No. 35/PUU-XI/2013 janganlah dianggap sebagai sebuah putusan penting yang mampu mereposisi dan meluruskan hak budget DPR sehingga mampu mencegah terjadinya perdagangan pengaruh dalam pembahasan RAPBN. Perlu juga ada pendalaman pengkajian untuk mencari model hak budget DPR yang ideal dan mampu mewujudkan APBN sebagai wujud kedaulatan rakyat sehingga keuangan negara mampu sebesar-besarnya untuk kemakmuran rakyat.

Selain harus dilakukan secara transparan dan akuntabel dalam penggunaan hak budget DPR, perlu juga penguatan sektor-sektor lain. Misalnya saja peran DPD dalam memberikan pertimbangan, peran MK dalam melakukan judicial review UU APBN, serta peran masyarakat. Selain itu yang lebih penting juga adalah memperkuat kapasitas dan daya dukung bagi DPR dalam melakukan analisis terhadap proposal RAPBN yang diajukan pemerintah sehingga mampu memberikan pengambilan keputusan yang tepat sesuai dengan tujuan bernegara.

\section{Penutup}

Eksistensi hak budget DPR dalam sistem ketatanegaraan Indonesia masih diakui dalam UUD 1945 Setelah Perubahan. Walaupun tidak secara expresses verbis disebutkan, hak budget melekat secara inheren dalam fungsi anggaran DPR sebagaimana disebutkan dalam Pasal 20A dan Pasal 23 Ayat (2) dan (3). Hak budget DPR tersebut ada sebagai perwujudan dianutnya kedaulatan rakyat (demokrasi), sehingga menempatkan posisi DPR lebih tinggi sebagai pemberi persetujuan dalam pembahasan RAPBN.

Bentuk keterlibatan DPR dalam pembahasan RAPBN sampai hal yang mendetil dan teknis yakni unit organisasi, fungsi, program, kegiatan, dan jenis belanja seringkali menimbulkan potensi korupsi anggaran. Keterlibatan DPR telah dipangkas oleh MK melalui Putusan No. 35/PUU-XI/2013 menjadi sampai ke unit organisasi, fungsi, dan program saja; namun masih menimbulkan persoalan terutama jika dikaitkan dengan persoalan transparansi serta kualitas proposal RAPBN yang sering kali masih bersifat inkrementalisme dan rutinisme. Karena itu diperlukan penelitian dan pengkajian yang mendalam untuk memperoleh hak budget DPR yang ideal sebagai bentuk kedaulatan rakyat sehingga APBN dapat diusahakan sebesar-besarnya untuk kemakmuran rakyat serta mencegah korupsi anggaran itu sendiri. 


\section{Daftar Pustaka}

\section{Buku}

A. Rivai, Hak Budget Dewan Perwakilan Rakyat dan Keuangan Daerah Otonom, NV Nix \& Co, Bandung, 1951.

Arifin P. Soeria Atmadja, Mekanisme Pertanggungjawaban Keuangan Negara Suatu Tinjauan Yuridis, Gramedia, Jakarta, 1986.

, Keuangan Publik dalam Perspektif Hukum, Teori, Kritik dan

Praktik, Rajawali Pers, Jakarta, 2009.

Black, Henry Campbel, Black's Law Dictionary Fourth Edition, West Publishing Co., St. Paul Minn, 1968.

C. Goedhart, Garis-Garis Besar Ilmu Keuangan Negara, terjemahan Ratmoko, Jakarta, 1973.

Dian Puji N. Simatupang, Paradoks Rasionalitas Perluasan Ruang Lingkup Keuangan Negara dan Implikasinya Terhadap Kinerja Keuangan Pemerintah, Badan PenerbitFHUI, Jakarta, 2011.

Hadji Muhammad Yamin, Naskah-Persiapan Undang-Undang Dasar 1945, Jilid Pertama, Cetakan Kedua, Yayasan Prapanca, Jakarta, 1971.

Jimly Asshiddiqie, Pokok-Pokok Hukum Tata Negara Paska Reformasi, Buana Ilmu Populer, Jakarta, 2008.

Lee, Robert D. Jr. \& Johnson, Ronald W., Public Budgeting System, Cetakan ke-2, Tokyo, 1977.

MPR, Panduan Pemasyarakatan Undang-Undang Dasar Negara Republik Indonesia Tahun 1945, Sekretariat Jenderal MPR RI, Jakarta, 2005.

Poerwadarminta, Kamus Umum Bahasa Indonesia, Jakarta, 1976.

Ronny Sautma Hotma Bako, Hak Budget Parlemen Indonesia, Yarsif Watampone, Jakarta, 2005.

Sudikno Mertokusumo dan A. Pitlo, Bab-Bab Tentang Penemuan Hukum, Citra Aditya Bakti, Bandung, 1993.

Yuna Farhan (ed), Anggaran Pro Kaum Miskin, Sebuah Upaya Menyejahterakan Masyarakat. Pustaka LP3ES, Jakarta, 2009.

\section{Dokumen Lain}

Bagir Manan, "Himpunan Tulisan Ilmiah Tentang Sistem Hukum Di Indonesia", dihimpun oleh Mahasiswa Program Doktor Ilmu Hukum Program Pascasarjana Universitas Padjadjaran Angkatan 2000/2001, Bandung, 2000.

Dian Puji N. Simatupang, "Reposisi Hak Budget DPR", Opini di Harian Kompas, Rabu, 18 Juni 2014.

Jared N. Nagel dan Justin Murray, "Past Government Shutdowns: Key Resources", Congressional Research Service, 29 September 2015.

Jimly Asshiddiqie, "Struktur Ketatanegaraan Indonesia Setelah Amandemen 
82 PJIH Volume 3 Nomor 1 Tahun 2016 [ISSN 2460-1543] [e-ISSN 2442-9325]

Keempat UUD 1945", Makalah disampaikan pada Seminar Pembangunan Hukum Nasional VIII, Denpasar, Bali, 14-18 Juli 2003.

Tempo, "Suap Anggota DPR Damayanti Diduga Tawarkan 20 Paket Proyek", https://nasional.tempo.co/read/news/2016/01/28/063740112/suapanggota-dpr-damayanti-diduga-tawarkan-20-paket-proyek, diakses 4 April 2016.

Yutirsa Yunus dan Reza Faraby, "Reduksi Fungsi Anggaran DPR Dalam Kerangka Checks and Balances", Jurnal Konstitusi, Vol. 7 No. 2 Agustus 2014.

\section{Dokumen Hukum}

Undang-Undang Dasar 1945 (Sebelum dan Sesudah Perubahan).

Konstitusi RIS 1949.

Undang-Undang Dasar Sementara 1950.

Undang-Undang Nomor 17 Tahun 2003 tentang Keuangan Negara.

Undang-Undang Nomor 27 Tahun 2009 tentang Majelis Permusyawaratan Rakyat, Dewan Perwakilan Rakyat, Dewan Perwakilan Daerah, dan Dewan Perwakilan Rakyat Daerah.

Undang-Undang Nomor 17 Tahun 2014 tentang Majelis Permusyawaratan Rakyat, Dewan Perwakilan Rakyat, Dewan Perwakilan Daerah, dan Dewan Perwakilan Rakyat Daerah.

Putusan Mahkamah Konstitusi No. 35/PUU-XI/2013. 